\title{
EQUILIBRIUM
}

Quarterly Journal of Economics and Economic Policy

2016 VOLUME 11 ISSUE 2, June

p-ISSN 1689-765X, e-ISSN 2353-3293

www.economic-policy.pl

Stefaniak-Kopoboru, J., \& Kuczewska, J. (2016). Export Specialization in Services of the Visegrad Countries. Equilibrium. Quarterly Journal of Economics and Economic Policy, 11(2), 265-284. DOI: http://dx.doi.org/10.12775/ EQUIL.2016.012

\author{
Joanna Stefaniak-Kopoboru* \\ Joanna Kuczewska** \\ University of Gdansk, Poland
}

\section{Export Specialization in Services of the Visegrad Countries}

\section{JEL Classification: $F 14 ; F 15$}

Keywords: international trade; services; specialization; comparative advantage; Visegrad countries

\begin{abstract}
The importance of services and the international trade in services is growing systematically. There are some reasons for that, especially the rapid development of IT technologies. This increase in the international trade in services is a global phenomenon, however there are some other specific issues, other than economic or technological, which might influence the trade in services in particular countries. As for the countries of the Central and Eastern Europe such a factor could be the accession to the European Union (EU).

The objective of the paper is to analyse the export specialization of the Visegrad countries in the international trade in services and how it changed over seven years after the EU accession. The service sector comprises of a variety of highly heterogeneous economic activities and the diversity of services is also reflected in the international trade of particular countries. Generally, the trade theories deal with trade of goods, but there are some attempts already to apply these theories for services. To find out the export specialization based on the comparative advantage in particular services, the main categories of services are analysed based on the
\end{abstract}

(C) Copyright Institute of Economic Research

Date of submission: April 3, 2015; date of acceptance: December 11, 2015

*Contact: jstefaniak@univ.gda.pl, Faculty of Economics, University of Gdansk, ul. Armii Krajowej 119, 81-824 Sopot, Poland

*** Contact: ekojku@ univ.gda.pl, Faculty of Economics, University of Gdansk, ul. Armii Krajowej 119, 81-824 Sopot, Poland 
adjusted RCA index assumptions. The analysis prepared in the paper is based on the balance of payment statistics provided by the WTO. The article is concluded by discussing the questions about the export specialization of particular countries and how it changed after the accession to the EU.

\section{Introduction}

The importance of services in the economies has been growing over the years. Services are also a growing component of the international trade worldwide. The same phenomenon applies to the economies of the Czech Republic, Hungary, Poland and Slovakia. These four Central European countries constitute the Visegrad Group - an alliance established in 1991 for the purposes of cooperation and furthering their European integration. In the last two decades, those countries have experienced significant changes in their political and economic development. The first change was a shift from the socialist planned economy to the market economy at the beginning of the 1990s, followed by signing the CEFTA agreement on the gradual creation of a free trade area between the Central European countries. And the second major change was the accession to the European Union in 2004. All those changes enabled the Visegrad countries to open to new markets and take advantage of the international trade not being bound by the previous agreements and boundaries of the Council for Mutual Economic Assistance (COMECOM). For all four states this freedom has resulted in increase of international trade, both in goods and services.

The basic objective of the paper is to analyse the export specialization of the Visegrad countries in the international trade in services using the Revealed Comparative Advantage (RCA) index and how it changed over time. The special emphasis is put on the period of accession to the European Union to find out if there was any influence of it on the Visegrad countries' international trade in services.

\section{Research Methodology}

Services are a very specific economic category. There are some discussion in the literature how to define services and how to measure the trade in services. Trade theories based on a concept of comparative advantage are widely used to analyse the trade in goods, however it is in the last two decades that economists have begun to examine how these theories might be applied to trade in services. In the second part of the study, the theoretical framework for the revealed comparative advantage concept is presented, 
followed by a discussion on the usefulness, or criticism on the application of this concept to the interpretation of patterns in the trade in services. The RCA index was constructed for the trade in goods purposes, but with setting two assumptions it might be used for analyzing the international trade in services as well.

The theoretical part of a study is followed by describing results. Firstly, the international trade in services if the Visegrad countries is analysed as for a volume and the share in the world's exports of services for years 1993-2011. The analysis is based on the balance of payment statistics provided by the WTO. The core part of the study starts with a calculation of RCA indices for each of the Visegrad countries corresponding to main types if services, such as: transportation, travel, communication services, construction, insurance services, financial services, computer and information, royalties and license fees, other business services, and finally personal, cultural and recreational services. The government services are not included. For the given RCA indices the trend analysis is made, and time trend coefficient checked for significance at the 5\% level. Then the tests of series are carried out to examine whether the values of RCA for the Visegrad countries before the accession to the European Union were significantly statistically different from the values after the accession. The year 2004 is taken as the first year of the European Union membership. A test using Fisher-Snedecor distribution to verify if the RCA index values were random (null hypothesis), or if a country's accession to the EU has resulted in statistically significant changes in the RCA values (alternative hypothesis) was conducted. The level of significance was set at 0.05 . The paper is concluded with a summary of achieved results.

\section{International Trade in Services}

Services in recent decades have come to play an increasingly important role in national economies (compare Francois \& Hoekman, 2010, pp. 642-692). Their share in GDP as well as in the creation of jobs is increasing. However, the growing importance of the services sector for the economies and economic growth does not correspond to the same extent on international trade in services. For many years, services have been considered as nontradablem due to specific features such as invisibility, non-storability, requirement of the physical contact between suppliers and consumers, close ties to movement of production factors (labour, capital), high level of specialisation and high trading costs (Grunfeld \& Moxnes, 2003; Markusen, 2005). But recent years brought a significant change, and services became 
internationally traded to much higher extent. This phenomenon is noticeable, especially since the beginning of XXI century, except for a crisis breakdown in years 2008-2008 (Fig.1). That resulted from two main factors: firstly due to the progress in communication technology and, secondly, due to the emergence of "new economy services", such as e-commerce, software production and other services (IMF, 2003). With the development of technology, the perception of services has changed. The possibilities provided by modern information and communication technologies have allowed for a relatively high degree of "independence" of services. In some cases, the usage of telecommunication or ICT networks has eliminated the proximity constrains. This allowed for breaking some ties between providers and consumers of services. Also an increase in the production of intermediate services and the growing importance of the outsourcing processes are largely responsible for the growth of international trade in services (Lennon, 2009).

Figure 1. Volume of world's export od services in years 1993-2013 (billion USD in current prices)

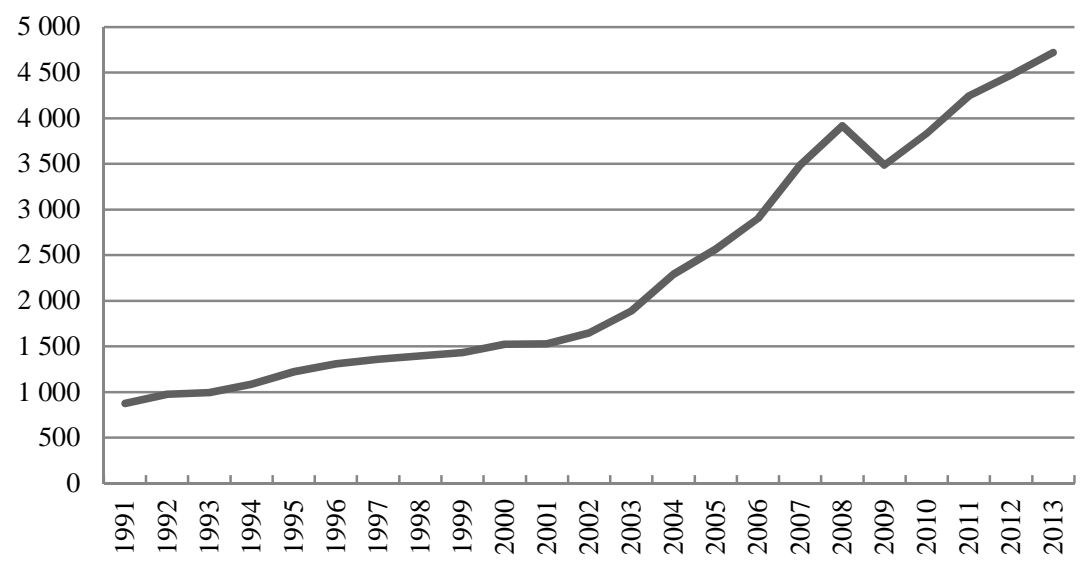

Source: own calculations based on WTO database (TsExports04564917).

Discussing international trade in services one has to be concerned with a problem of how to measure it. In the literature there are two definitions of international mobility of services: first one used by IMF or WTO and another one used by GATS. The first definition assumes that international trade occurs only when the two parties involved reside in two different states. These transactions are covered by balance of payments statistics and 
consist of the following categories of services: transportation, travel and other services: communication services, construction services, computer and information services, insurance, financial services, royalties and license fees, other business services, personal, cultural and recreational services, government services.

A much wider definition was accepted in GATS, where four modes of supply were recognized:

- mode 1 - cross-border supply,

- mode 2-consumption abroad,

- mode 3-commercial presence (foreign direct investments),

- mode 4 - presence of natural persons (compensation of employees and workers' remittances as approximate indicators of the mode).

This concept of mobility of services identifies all services as tradable (they can be provided and consumed under one mode or another) and covers all possible ways they can be delivered internationally (Kuźnar, 2007).

The data collected by IMF or WTO based on the balance of payments that apply to the first definition do not correspond with the GATS's modes of supply. For this paper's purpose, we are using the nomenclature of trade in services used by the WTO, although we will not consider government services in this study.

\section{Revealed Comparative}

\section{Advantage - Theoretical Framework}

The concept of comparative advantage was introduced by David Ricardo in 1817. Since then, many economists have expanded the basic theoretical framework developed by Ricardo. They also tested the extent to which the theory of comparative advantage can be used to explain existing patterns of trade, however it is only in recent years that they have begun to examine how the existing theories could be applied to services (Feketekuty, 1988).

Comparative advantage means that every country can gain from trade if it concentrates its energies in the industries that make the best use of its resources and skills (Feketekuty, 1988). Therefore, according to trade theories, countries usually tend to specialize in exports of those services where they have a comparative advantage (Balassa, 1965; Deardoff 1985).

Generally trade theories deal with trade in goods, but considering the growing importance of services in the international trade, there are some discussions on trade theories for services going on (Deardoff, 1985; Stern \& Hoekman, 1987; Snape, 1990; Stibora \& De Vaal, 1995; Markusen, 2005). Although services in their characteristics differ significantly from 
goods, it might be assumed that to some extent the general ideas of trade theories for goods can be also applied to services, and they can give some useful insights about trade in services (Hindley \& Smith, 1984; Stern \& Hoekman, 1987; Feketekuty, 1988). The problem with trade in services is that it is largely invisible and it is tied to the international flow of people, information, capital and goods, and it is closely tied to foreign investments in the importing country. Therefore, it is difficult to identify precisely what is being traded. But Feketekuty (1988) emphasizes that the unique characteristics of trade in services do not invalidate the application of existing international trade theory, but the existing theory will have to be expanded to deal with the unique aspects of trade in services.

There is also some criticism on the applicability of the concept of comparative advantage to international trade in services. Prieto (1989) argues that to extend to which markets become increasingly globalized, the concept of comparative advantage ceases to be relevant as in the theory it is valid only when there is no mobility of production factors. He also points out that more than endowment of physical resources (land and capital) there are few other key elements that determine comparative advantage in trade in services. These are: information resources, country's telecommunication infrastructure, orientation and volume of funds spent on investment and development, level and skill of labour, and the reliability projected by a given service supplier. The importance of other factors than physical endowment is also recognised by Daniels (1993) and Langhammer (2004). Daniels, in the case of trade in services, sees the importance of finance capital, political and cultural factors, characteristics of human capital, the pattern and level of existing development in a country. However, in the opinion of Langhammer (2004), comparative advantage for service trade cannot be compared to comparative advantage for goods trade because it follows other determinants, such as existences of different modes of supply, domestic policy factors and specifics of factor movements.

Despite all the discussion for and against it, the concept of comparative advantage has already a permanent place in the economic literature. But the question of how to measure is still being discussed. Attempts to quantify the comparative advantage have been made by many economists: e.g. Liesner (1958), Balassa (1965), Donges \& Riedel (1977), Bowen (1983), Vollrath (1991), Dalum et al. (1998), Laursen (1998), or Proudman \& Redding (2000).

Initial work on the determination of the strengths of the economy by analysing the structure of exports was carried by Liesner in 1958. A similar approach was adopted by Bela Balassa in 1965, by publishing a formula that allows for identification of those areas of the economy where a country 
has a comparative advantage. Index Revealed Comparative Advantage is currently the most commonly used indicator to measure the competitive position in international trade (Mongiało, 2007; Lee, 2010). The traditional formula for this indicator was the subject of much criticism and attempts were made to modify it (Laursen, 1998; Yeats, 1985; Proudman \& Redding, 2000). However, the primary version of the index remains popular and is widely used in the literature.

Originally the RCA index was concerned with trade in goods (OECD, 2003). This was a consequence of the development of the theory of international trade. But a stable growth in international trade in services as a result of globalization, technological changes, stronger international economic relations, especially between developed countries, was the impetus for the theoretical and empirical analysis explaining the issues of international trade in services (Wróbel, 2009). This index was created for international trade in goods, however with setting up two assumptions it might be used for analysing international trade in services (Deardoff, 1985; Mongiałło, 2007). Those assumptions are as follow: 1. trade model reflects relative costs and differences in elements other than prices, 2. trade emerges between countries as a result of differences in endowments of economic resources, not as result of differences in technologies.

Revealed Comparative Advantage (RCA) index is defined as (Balassa, 1965):

$$
R C A_{i j}=\frac{X_{i j} / \sum_{i} X_{i j}}{\sum_{j} X_{i j} / \sum_{i} \sum_{j} X_{i j}}
$$

where:

$X_{i j}-$ exports of sector $i$ from country $j$,

$\sum_{i} X_{i j}$ - total exports from country $j$

$\sum_{j} X_{i j}$ - exports of sector $i$ from the reference group,

$\sum_{i} \sum_{j} X_{i j}$ - total exports from the reference group.

The RCA index is the key indicator that measures the degree of export specialization in a particular product or industry. The equation defines export specialisation in terms of country j's share in relevant group of countries exports of product $i$ in relation to country j's share of total services exports in reference group total services exports. In other words, it expresses if the country possess a comparative advantage in the international exports of goods or groups of goods in relation to the share of the country's total exports in exports of countries taken as a benchmark. As a reference (benchmark) group, a set of countries which provides a sufficient infor- 
mation on trade can be taken. Traditionally, there are two sources of data used: OECD and World Trade Organization (WTO). Therefore, choosing one of those two sources the reference group is defined. For this paper, the WTO database was used.

The RCA can range from 0 to infinity. When RCA index equals 1 for a given sector in a given country, the percentage share of that sector is identical with the reference group average. When RCA is above 1 the country is said to be specialized in that sector exports, while the RCA is below 1, then there is no specialization. The closer to 0 the less important is that given sector in the country's export. And vice versa - the higher result the domination of particular sector in the country's exports is greater.

\section{International Trade in Services of the Visegrad Countries}

The world's international trade in services in 2013 accounted for 4720,2 billion USD. The major players in terms of their export share were developed countries: The United States $(13,96 \%$ of world's trade in services), the United Kingdom (6,75\%) and Germany $(6,08 \%)$. The total export of the Visegrad group amounted to 90,6 billion USD (1,92\%). And individually Poland was placed on the 31 position among 185 countries that had reported to the World Trade Organization (with $0,86 \%$ of share in the world trade in services), the Czech Republic placed 36 (0,53\%), Hungary $37(0,50 \%)$ and Slovak Republic $62(0,15 \%)$.

Taking into account changes over time after the increase in the first half of 1990s, the share of the Visegrad countries in the world's trade in services decreased and stayed around the level of 1,6\% for few years. The accession to the European Union had a positive impact on international trade in services for all four Visegrad countries what resulted in significant increase in volume of service trade for the Group (37 billion USD in 2004 up to nearly 91 billion USD in 2013) and in increase in its share in the world's trade (1,63\% in 2004 up to 2,19\% in 2008 and 2,08\$ in 2011) (Fig. 2 and 3). 
Figure 2. Volume of exports of services for the Visegrad countries in years 1993-2013 (billion USD)

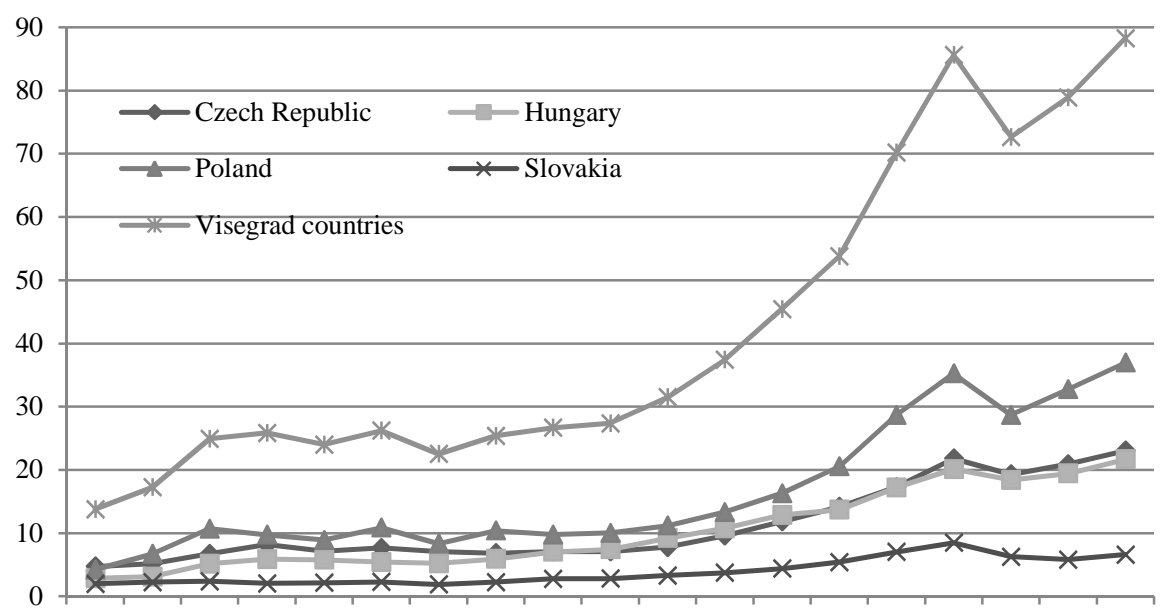

1993199419951996199719981999200020012002200320042005200620072008200920102011

Source: own calculations based on WTO database (TsExport04564917).

Figure 3. Share of the Visegrad countries' exports of services in world's export in years 1993-2013 (\%)

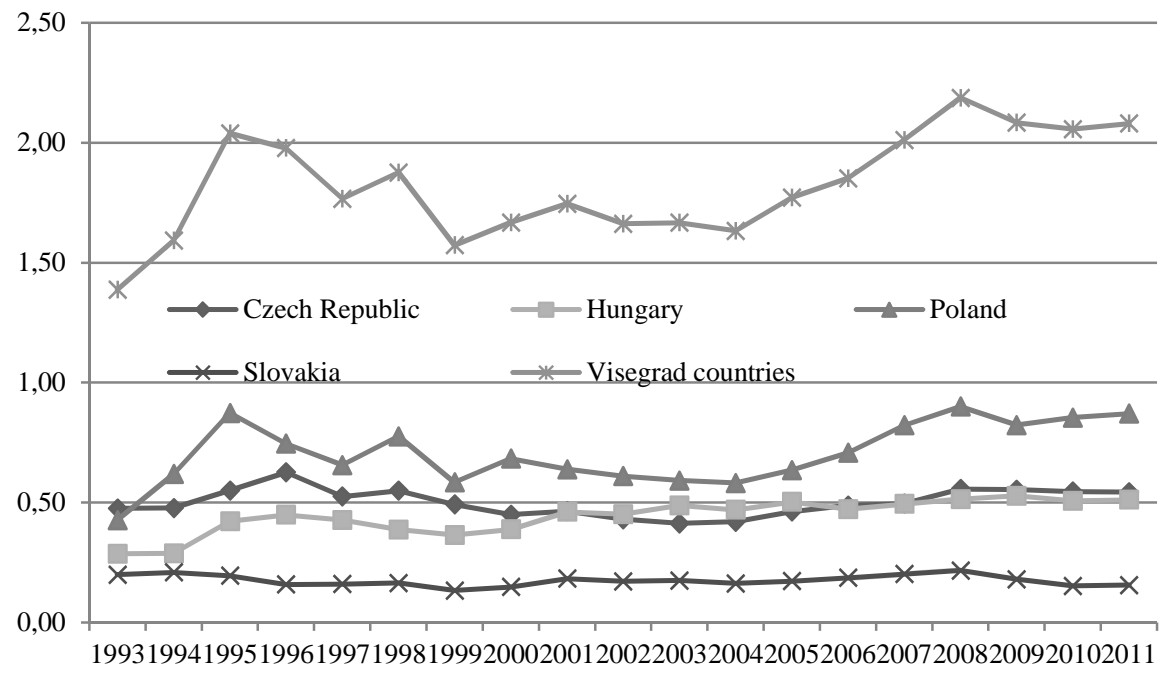

Source: own calculations based on WTO database (TsExport04564917). 


\section{Specialisation in Exports of Services}

The service sector comprises of a variety of highly heterogeneous economic activities. This diversity of services is also reflected in the international trade of particular countries (Table 1).

Table 1. The RCA Indices for the Visegrad Countries

\begin{tabular}{|c|c|c|c|c|c|c|c|c|c|c|c|c|c|c|}
\hline Country & 2000 & 2001 & 2002 & 2003 & 2004 & 2005 & 2006 & 2007 & 2008 & 2009 & 2010 & 2011 & 2012 & 2013 \\
\hline \multicolumn{15}{|c|}{$\begin{array}{ll}\text { Transportation } \\
\end{array}$} \\
\hline Czech Rep. & 0,90 & 0,96 & 1,13 & 1,30 & 1,29 & 1,11 & 1,11 & 1,18 & $\mathbf{1 , 0 8}$ & 1,24 & 1,17 & 1,17 & 1,17 & 1,23 \\
\hline Hungary & 0,39 & 0,37 & 0,44 & 0,52 & 0,56 & 0,75 & 0,88 & 0,88 & 0,86 & 0,95 & 0,94 & 1,05 & 1,09 & 1,22 \\
\hline Poland & 1,04 & 1,24 & $\mathbf{1 , 5 1}$ & 1,68 & 1,43 & $\mathbf{1 , 5 1}$ & $\mathbf{1 , 5 5}$ & 1,47 & 1,36 & 1,54 & 1,30 & 1,45 & 1,48 & $\mathbf{1 , 5 9}$ \\
\hline Slovakia & 1,97 & 1,63 & 1,92 & 2,01 & $\mathbf{1 , 8 3}$ & 1,63 & 1,61 & 1,45 & 1,51 & $\mathbf{1 , 5 9}$ & 1,48 & $\mathbf{1 , 5 5}$ & 1,43 & 1,47 \\
\hline \multicolumn{15}{|c|}{$\begin{array}{c}\text { Travel } \\
\end{array}$} \\
\hline Czech Rep. & 1,38 & 1,42 & 1,40 & 1,59 & 1,55 & $\mathbf{1 , 5 0}$ & $\mathbf{1 , 5 9}$ & 1,59 & 1,46 & 1,46 & 1,39 & 1,36 & 1,29 & 1,29 \\
\hline Hungary & 2,01 & 1,92 & 1,68 & 1,54 & 1,30 & 1,18 & 1,19 & 1,09 & 1,20 & 1,24 & 1,14 & 1,04 & 0,96 & 0,95 \\
\hline Poland & 1,73 & 1,55 & 1,44 & 1,27 & $\mathbf{1 , 5 4}$ & 1,42 & 1,35 & 1,46 & 1,34 & 1,23 & $\mathbf{1 , 2 0}$ & 1,16 & 1,17 & 1,13 \\
\hline Slovakia & 0,61 & 1,10 & 0,88 & 0,91 & 0,86 & 1,01 & 1,07 & 1,14 & 1,24 & 1,56 & $\mathbf{1 , 5 7}$ & 1,51 & 1,30 & 1,34 \\
\hline \multicolumn{15}{|c|}{ Communications services } \\
\hline Czech Rep. & 0,81 & 1,31 & 1,11 & 0,59 & 1,01 & 1,43 & 1,28 & 1,45 & 1,11 & 1,08 & 1,03 & 0,91 & 0,90 & 0,96 \\
\hline Hungary & 0,53 & 0,59 & 0,78 & 1,01 & 1,20 & 1,15 & 1,19 & $\mathbf{1 , 0 7}$ & 1,08 & 0,96 & 0,94 & 0,68 & 0,61 & 0,53 \\
\hline Poland & 1,02 & 0,90 & 0,76 & 0,97 & 0,99 & 0,82 & 0,79 & 0,74 & 0,70 & 0,85 & 0,68 & 0,64 & 0,58 & 0,53 \\
\hline Slovakia & 1,04 & 0,89 & 0,95 & 1,03 & 0,98 & 1,11 & 1,92 & 1,53 & 1,47 & 1,36 & 1,31 & 0,70 & 1,11 & 0,74 \\
\hline \multicolumn{15}{|c|}{ Construction } \\
\hline Czech Rep. & 1,20 & 1,06 & 0,80 & 0,69 & 0,60 & 0,91 & 0,67 & 0,76 & 0,78 & 0,82 & 1,83 & 1,52 & 1,57 & 1,25 \\
\hline Hungary & 0,80 & 0,66 & 1,13 & 1,03 & 0,76 & 0,62 & 1,23 & 1,22 & 1,08 & 0,86 & 0,78 & 0,81 & 0,76 & 0,81 \\
\hline Poland & 1,40 & 2,12 & 2,56 & 3,14 & 2,41 & 2,41 & 2,56 & 2,26 & 1,88 & 1,68 & 1,58 & 1,76 & 1,75 & 1,71 \\
\hline Slovakia & 1,49 & 1,17 & 0,85 & 1,25 & 1,49 & 1,22 & 0,68 & 0,70 & 0,75 & 0,68 & 1,10 & 1,70 & 1,88 & 1,91 \\
\hline \multicolumn{15}{|c|}{ Insurance services } \\
\hline Czech Rep. & 0,02 & 0,06 & 0,05 & 0,01 & 0,03 & 0,28 & 0,25 & 0,26 & 0,46 & 0,45 & 0,53 & 0,52 & 0,60 & 0,58 \\
\hline Hungary & 0,16 & 0,13 & 0,07 & 0,12 & 0,15 & 0,03 & 0,05 & 0,06 & 0,07 & 0,04 & 0,06 & 0,06 & 0,07 & 0,08 \\
\hline Poland & 1,19 & 1,04 & 0,79 & 0,68 & 0,19 & 0,22 & 0,22 & 0,03 & 0,19 & 0,03 & 0,22 & 0,46 & 0,41 & 0,24 \\
\hline Slovakia & 0,32 & 0,16 & 0,21 & 0,18 & 0,21 & 0,11 & 0,09 & 0,15 & 0,23 & 0,44 & 0,27 & 0,16 & 0,36 & 0,31 \\
\hline \multicolumn{15}{|c|}{$\begin{array}{r}\text { Financial services } \\
\end{array}$} \\
\hline Czech Rep. & 0,84 & 0,44 & 0,41 & 0,35 & 0,66 & 0,51 & 0,36 & 0,20 & 0,11 & 0,05 & 0,04 & 0,05 & 0,03 & 0,02 \\
\hline Hungary & 0,38 & 0,37 & 0,31 & 0,32 & 0,35 & 0,16 & 0,15 & 0,17 & 0,16 & 0,13 & 0,12 & 0,12 & 0,11 & 0,13 \\
\hline Poland & 0,15 & 0,28 & 0,21 & 0,22 & 0,18 & 0,19 & 0,14 & 0,16 & 0,20 & 0,20 & 0,23 & 0,18 & 0,17 & 0,18 \\
\hline Slovakia & 0,25 & 0,15 & 0,37 & 0,27 & 0,36 & 0,45 & 0,35 & 0,46 & 0,31 & 0,14 & 0,10 & 0,07 & 0,09 & 0,11 \\
\hline
\end{tabular}


Table 1 continued

\begin{tabular}{|c|c|c|c|c|c|c|c|c|c|c|c|c|c|c|}
\hline Country & 2000 & 2001 & 2002 & 2003 & 2004 & 2005 & 2006 & 2007 & 2008 & 2009 & 2010 & 2011 & 2012 & 2013 \\
\hline \multicolumn{15}{|c|}{ Computer and information services } \\
\hline Czech Rep. & 0,43 & 0,50 & 0,56 & 0,24 & 0,35 & 1,31 & 1,52 & 1,24 & 1,28 & 1,28 & 1,10 & 1,37 & 1,56 & 1,57 \\
\hline Hungary & 0,64 & 0,72 & 0,74 & 0,66 & 0,74 & 0,71 & 0,83 & 1,09 & 1,12 & 1,17 & 1,10 & 1,04 & 1,09 & $\mathbf{1 , 0 7}$ \\
\hline Poland & 0,18 & 0,25 & 0,27 & 0,30 & 0,35 & 0,29 & 0,44 & 0,52 & 0,53 & 0,57 & 0,86 & 0,99 & 1,09 & 1,21 \\
\hline Slovakia & 0,73 & 0,70 & 0,69 & 0,63 & 0,74 & 0,63 & 0,70 & 0,67 & 0,72 & 0,88 & 1,07 & 1,52 & 1,32 & 1,23 \\
\hline \multicolumn{15}{|c|}{ Other business services } \\
\hline Czech Rep. & 0,96 & 0,97 & 0,94 & 0,78 & 0,70 & 0,76 & 0,75 & 0,81 & 1,05 & 0,97 & 1,00 & 1,01 & 0,99 & 0,96 \\
\hline Hungary & 0,65 & 0,62 & 0,83 & 0,95 & 1,07 & 1,09 & 1,10 & 1,13 & 1,17 & 1,08 & 1,15 & 1,19 & 1,19 & 1,08 \\
\hline Poland & 0,58 & 0,57 & 0,53 & 0,59 & 0,61 & 0,69 & 0,76 & 0,77 & 0,94 & 1,01 & 1,17 & 1,03 & 0,99 & 0,95 \\
\hline Slovakia & 1,05 & 0,74 & 0,83 & 0,72 & 0,72 & 0,74 & 0,70 & 0,69 & 0,69 & 0,53 & 0,57 & 0,58 & 0,81 & 0,83 \\
\hline \multicolumn{15}{|c|}{$\begin{array}{l}\text { Royalties and license fees } \\
\end{array}$} \\
\hline Czech Rep. & 0,12 & 0,10 & 0,12 & 0,12 & 0,07 & 0,06 & 0,04 & 0,04 & 0,04 & 0,08 & 0,08 & 0,07 & 0,14 & 0,17 \\
\hline Hungary & 0,34 & 0,25 & 0,86 & 0,64 & 0,87 & 1,11 & 0,72 & 0,91 & 0,74 & 0,67 & 0,81 & 0,71 & 0,82 & 0,85 \\
\hline Poland & 0,06 & 0,09 & 0,06 & 0,05 & 0,04 & 0,07 & 0,03 & 0,06 & 0,11 & 0,05 & 0,11 & 0,11 & 0,09 & 0,12 \\
\hline Slovakia & 0,13 & 0,13 & 0,25 & 0,28 & 0,28 & 0,29 & 0,30 & 0,36 & 0,33 & 0,23 & 0,12 & 0,01 & 0,01 & 0,01 \\
\hline \multicolumn{15}{|c|}{ Personal, cultural and recreational } \\
\hline Czech Rep. & 1,72 & 1,57 & $\mathbf{1 , 5 7}$ & 0,99 & 1,49 & 0,61 & 0,67 & 1,47 & 0,75 & 0,90 & 1,09 & 1,22 & 1,27 & 1,24 \\
\hline Hungary & 2,25 & 5,90 & 4,82 & 6,44 & 7,75 & 7,93 & 6,25 & 10,29 & 6,61 & 7,44 & 7,71 & 7,82 & 7,73 & 8,26 \\
\hline Poland & 0,31 & 0,47 & 0,41 & 0,36 & 0,49 & 0,46 & 0,58 & 0,87 & 0,77 & 0,62 & 1,11 & 1,59 & 1,16 & 1,05 \\
\hline Slovakia & 1,55 & 1,69 & 1,61 & 1,48 & 2,36 & 2,24 & 2,29 & 5,96 & 1,98 & 1,63 & 1,42 & 1,46 & 1,26 & 0,68 \\
\hline
\end{tabular}

Bold - RCA above 1

Source: own calculations based on WTO database (TsExport04564917).

For the given RCA indices time trend analysis was made and time trend coefficient check for significance using Fisher-Snedecor distribution at the 5\% level. There were also calculations made using t-test to examine whether the values of RCA for the Visegrad countries before the accession to the EU were significantly statistically different from the values after the accession in 2004 (the year 2004 was taken as a first year of the European Union membership). The level of significance was set at 0.05 . 
Table 2. The Estimated Time Trend Coefficient of RCA Indices

\begin{tabular}{lcccc}
\hline Services & $\begin{array}{c}\text { Czech } \\
\text { Republic }\end{array}$ & Hungary & Poland & Slovakia \\
\hline Transportation & 0,019 & 0,053 & $\mathbf{0 , 0 0 4}$ & 0,017 \\
\hline Travel & $\mathbf{0 , 0 0 3}$ & $-0,046$ & 0,026 & 0,042 \\
\hline Communication & $\mathbf{- 0 , 0 0 4}$ & $-0,006$ & $-0,031$ & $\mathbf{0 , 0 0 2}$ \\
\hline Construction & 0,047 & $-0,004$ & $-0,052$ & 0,032 \\
\hline Insurance & 0,052 & $-0,005$ & $-0,058$ & 0,008 \\
\hline Financial services & $-0,055$ & $-0,023$ & $-0,002$ & $-0,017$ \\
\hline Computer and information & 0,097 & 0,042 & 0,077 & 0,054 \\
\hline Royalties and licence fees & $\mathbf{0 , 0 0 1}$ & 0,024 & 0,004 & $-0,014$ \\
\hline Other business services & 0,010 & 0,037 & 0,045 & $-0,014$ \\
\hline Personal, cultural and recreational & $-0,032$ & 0,292 & 0,077 & $\mathbf{- 0 , 0 4 1}$ \\
\hline bold
\end{tabular}

bold - statistically significant at the 5\% level

- t-test - statistically significant change from 2004

Source: own calculations based on WTO database (TsExport04564917).

\section{Transportation services}

Transport is usually one of the biggest sub-sectors of services in terms of its share in the national economy and in employment. It is also very heterogeneous itself, consisting of sea, air and other including land, internal waterway, space and pipeline transport services that are performed by residents of one economy for those of another, and that involve the carriage of passengers, the movement of goods (freight), rentals (charters) of carriers with crew, and related supporting and auxiliary services (WTO, 2013). The significance of that sub-sector depends on few factors whether the most important ones are geographical location and transport infrastructure.

The country with the highest RCA in transport services is Slovakia. In the pre-accession time the share of exports of transport services in the total Slovakia's exports was very high. The accession to the European Union in 2004 resulted in decrease of the RCA values to 1,5 level, however it is still the highest RCA in this sub-sector amongst the Visegrad countries. Also Poland specialises in exports of transport services - the RCA values are above 1 and there were no significant changes in the level of RCA during the analysed time, however after accession to the EU the situation in the exports of this sub-sector was stabilised. For the Czech Republic and Hungary there was an increase in specialization in transport services (both has statistically significant trends). Especially Hungary has noticed a very positive trend towards the specialisation in exports of transport services.

For all four countries the accession to the European Union had an impact on their exports specialisation in transport services, although it was different for different countries. The impact on the Czech Republic and 
Hungary was positive and the exports specialization in transport services was improving, in Poland the level of exports specialization stabilized, whereas Slovakia was losing its dominance.

\section{Travel services}

Travel services are a broad category that includes goods and services acquired by personal travellers, for health, education or other purposes, and by business travellers. Unlike other services, travel is not a specific type of service, but an assortment of goods and services consumed by travellers. The most common goods and services covered are lodging, food and beverages, entertainment and transportation (within the economy visited), gifts and souvenirs (WTO, 2013).

At the beginning of the analysed time three out of four Visegrad countries specialised in exports of travel services: Hungary, Poland and the Czech Republic. Since 2004 all four countries had RCA above 1, although only for Slovakia the RCA values show a statistically significant upward trend and in 2011 Slovakia was specialized in exports of travel services in the highest extend. For other three countries time trend coefficient was negative. The largest decrease was noted for Hungarian exports specialisation, however accession to the EU had slowed down the decline. For other Visegrad countries the accession to the European Union had no significant importance for their exports specialisation in travel services.

\section{Communication services}

Any of the four Visegrad countries had a permanent exports specialisation in communication services, which is a very broad category and encompasses the transmission of sound, images or other information by telephone, telex, telegram, radio and television cable and broadcasting, satellite, electronic mail, facsimile services etc., including business network services, teleconferencing and support services. Also included are cellular telephone services, internet backbone services and on-line access services, including provision of access to the internet (WTO, 2013).

Before 2004 the values of the RCA indices varied significantly for all countries. After the accession to the EU in 2004 there was firstly an increase in exports specialisation in the sub-sector for Slovakia, the Czech Republic and Hungary, but since 2006/2007 there was a downturn in RCA values. There is no export specialisation in communication services for Poland and calculations show that revealed comparative advantage in this sub-sector for Poland was characterised by a statistically significant nega- 
tive trend. The accession to the EU had no a significant impact on exports specialisation for any of the Visegrad countries.

\section{Construction services}

In the exports of construction services, which cover the work performed on construction projects and installation of an enterprise by employees in locations outside the territory of the enterprise (WTO, 2013), the Visegrad countries are differentiated. The highest level of specialisation was recorded in Poland, however since 2003 there has been a significant slowdown in the exports share (from 3,14 in 2003 to 1,63 in 2011). For the other countries RCA indices did not indicate a specialisation in exports of construction services, although after 2009 the exports in this sub-sector revealed an increase in the comparative advantage for the Czech Republic and Slovakia. For all Visegrad countries, the test of series shows that the accession to the EU had no significant statistical effect on their exports specialisation in construction services.

\section{Insurance services}

Insurance services are very specific in nature. They might be traded internationally, however traditionally customers prefer direct contact with insurers, especially when claims procedures are being conducted. None of the Visegrad countries revealed exports specialisation in insurance services. Only for Poland prior to 2003 RCA indices in exports of insurance services achieved levels above or close to 1 . After 2003 the share of these services in Poland's exports dropped significantly.

Low RCA indices for exports of insurance services might be explained twofold. Firstly that most of the insurance services might be internationally traded in the form of foreign direct investments. And secondly, since the end of 1990s the ownership structure in insurance companies operating in the Visegrad countries has been changing significantly towards the greater share of foreign capital (e.g. in Hungary insurance companies are nearly $100 \%$ foreign owned), which influenced the level of exports and imports of insurance services.

As the tests of series revealed Poland was the only of the Visegrad states that accession to the EU had an impact on exports specialisation in this subsector. 


\section{Financial services}

In the financial services sub-sector the situation is nearly the same as for the insurance services, usually because financial services and insurance services are very closely related. Very often the same financial institutions (e.g. banks) offer both financial and insurance products. Financial services as a sub-sector covers financial intermediation and auxiliary services provided by banks, stock exchanges, factoring enterprises, credit card enterprises, and other enterprises (WTO, 2013).

Calculations of the RCA show that none of the Visegrad countries has revealed comparative advantage in exports of the financial services. Moreover, time trends are negative and statistically significant. The worst situation during the analysed period appeared in the Czech Republic, where the downward slope was negative to the highest extent.

During the whole analysed period, the exports of financial services were decreasing steadily and there was no a significant impact of the accession to the European Union.

\section{Computer and information services}

Computer and information services are subdivided into computer services (hardware and software related services and data processing services), news agency services, and other information provision services (database services and web search portals) (WTO, 2013). This type of services gains importance since the 1990s as the development of new technologies is progressing.

In this services sub-sector all Visegrad countries noted statistically significant positive trends. The Czech Republic, Slovakia and Hungary noted increasing comparative advantage over analysed time reaching RCA indices above 1 . Poland was the only state that was characterised by RCA below 1, however the share of computer and information services in total Polish exports has been permanently increasing. The increasing role of these services in exports seems to be a natural process, while test of series has not revealed any significant impact of the EU's accession except for the Czech Republic.

\section{Royalties and license fees}

The royalties and license fees cover payments and receipts for the use of intangible non-financial assets and proprietary rights, such as patents, copyrights, trademarks, industrial processes, and franchises (WTO, 2013). These 
services arise usually as effects of research and development investments, as well as investments in education and technology. These investments in countries of Central and Eastern Europe tend to be rather low, and as a result any of the Visegrad countries specialize in exports of royalties and fees. In overall, their competitive position in this category of services was very low. The best position in this sub-sector was noted for Hungary, however only in 2005 the RCA for Hungary exceeded 1. The accession to the European Union did not have a special impact on exports of those services in any of the Visegrad countries.

\section{Other business services}

Other business services consist mainly of business-to-business services and they are characterised by Markusen (2005) as knowledge-intensive requiring a high initial investments in human capital. This is a sub-sector that is intensive in skilled labour and whose final products are highly differentiated. These category includes trade-related services, operational leasing (rentals), and miscellaneous business, professional and technical services such as legal, accounting, management consulting, public relations services, advertising, market research and public opinion polling, research and development services, architectural, engineering, and other technical services, agricultural, mining and on-site processing (WTO, 2013).

During the analysed period only Slovakia was constantly losing its competitiveness in other business services. The other three countries were systematically increasing exports of those services achieving the level of RCA above 1 for all of them in 2011.

The accession to the European Union had statistically significant positive effect on exports of Hungary and Poland. In the case of Poland, exports of other business services accelerated to reach 1,01 in 2009 from 0,53 in 2002, whereas for Hungary since 2004 the comparative advantage measured by RCA was stabilised at the level above 1 .

\section{Personal, cultural, and recreational services}

Personal, cultural, and recreational services are subdivided into two categories: audiovisual services, and other cultural and recreational services. The first component includes services and fees related to the production of motion pictures, radio and television programmes, and musical recordings. The second category services includes services such as those associated with museums, libraries, archives, and other cultural, sporting, and recreational activities (WTO, 2013). 
The country that highly specialises in personal, cultural and recreational services is Hungary. It noted the highest level of RCA index in $2005(7,93)$, and since then its competitiveness has been slightly decreasing, however it still stayed above 5. Also Slovakia specialised in exports of this category of services. On the other extreme there is Poland, where the competitive position was quite low until recent years. The Czech Republic was losing its competitiveness, and since 2004 the comparative advantage index has been achieving values below 1 . The Czech Republic was also the only of the Visegrad countries for which the test of series revealed a significant negative impact of the accession to the European Union on the share of this category of services in the country's total export.

\section{Conclusions}

Services are growing in importance in international trade for all four Visegrad countries. There are 10 main categories of services covered by the WTO statistics: transportation, travel, communication services, construction services, computer and information services, insurance, financial services, royalties and license fees, other business services, as well as personal, cultural and recreational services. To find out the Visegrad countries degree of specialisation in international trade in different types of services the Revealed Comparative Advantage index was calculated. We found out that in years of 2000-2011:

- The Czech Republic specialised in transportation, travel, communication services as well as computer and information services. But during that time it lost its competitiveness in personal, cultural and recreational services.

- Hungary specialised in personal, cultural and recreational services. The level of competitiveness in this type of services was overwhelming all other types of services in Hungary's exports and it was the highest level amongst all Visegrad countries. Hungary specialised also in exports of travel and communication services, and with time it gained competitiveness in computer and information services as well as in other financial services.

- Poland had the greatest comparative advantage in construction services followed by transportation services and travel services. After 2009 there was an increase in specialisation in other business services.

- Slovakian comparative advantage was the greatest in transportation services and personal, cultural and recreational services. This country specialised also in exports of travel services, communication services 
and construction services. At the end of analysed period computer and information services were gaining a greater share in Slovakian total exports of services.

- All Visegrad countries had a very low level of comparative advantage in exports of insurance and financial services as well as in royalties and licenses fees.

In 2004 the Czech Republic, Hungary, Poland and Slovakia became members of the European Union. Basing on the results of the test of series, we noticed that the accession to the EU had some positive effects on the total exports of services for the whole Visegrad group. However, this influence was different for particular countries and types of services. For all Visegrad countries, the influence of the membership had an effect on exports of transportation services. Although for the Czech Republic and Hungary this impact was positive, for Slovakia negative and for Poland the accession to the EU had a stabilising effect on exports of transportation services. The positive impact of the EU membership was noted in exports of computer and information services in the Czech Republic and in exports of other business services for Hungary and Poland. Also the influence of membership on the exports of travel services for Hungary should be appraised as positive, while it hampered the rapid decline in the comparative advantage that Hungary experienced in the pre-accession time. On the other hand, the negative effect of the accession was noted for exports of insurance services of Poland.

The conclusions based on the calculations of the RCA and test of series are that in years of 2000-2011 all Visegrad countries experienced changes in the level of their export specialisations in different types of services, but the very moment of the accession to the European Union had not a special impact on those changes, while they rather emerged from the natural economic development and changes in the national economies deriving from the harmonisation and adaptation to the requirements of the European Union membership that started after signing the association agreements at the beginning of 1990s of the twentieth century. 


\section{References}

Balassa, B. (1965). Trade Liberalization and "Revealed" Comparative Advantage. Manchester School of Economic and Social Studies, 33. DOI: http://dx.doi.org/10.1111/j.1467-9957.1965.tb00050.x.

Dalum, B., Laursen, K., \& Villumsen, G. (1998). Structural Change in OECD Export Specialisation Patterns: De-specialisation and 'Stickiness'. International Review of Applied Economics, 12(3). DOI: http://dx.doi.org/10.1080/026921 79800000017.

Daniels, P. W. (1993). Service Industries in the World Economy. Oxford: Blackwell.

Deardorff, A. V. (1985). Comparative Advantage and International Trade and Investment in Services. Research Seminar in International Economics, Gerald R. Ford School of Public Policy, The University of Michigan, Post-Print Paper, 5.

Donges, J. B., \& Riedel, J. (1977). The Expansion of Manufactured Exports in Developing Countries: An Empirical Assessment of Supply and Demand Issues. Weltwirtschaftliches Archiv, 113(1).

Feketekuty, G. (1988). International Trade in Services: An Overview and Blueprint for Negotiations. Cambridge Massachusets: Bullinger Pub Co.

Francois, J., \& Hoekman, B. (2010). Services Trade and Policy. Journal of Economic Literature, 48(3). DOI: http://dx.doi.org/10.1257/jel.48.3.642.

Grunfeld L., \& Moxnes, A. (2003). The Intangible Globalization: Explaining the Patterns of International Trade in Services. Norwegian Institute of International Affairs, Working Paper, 657.

Hindley, B., \& Smith, A. (1984). Comparative Advantage and Trade in Services. World Economy, 7(4). DOI: http://dx.doi.org/10.1111/j.1467-9701.1984. tb00071.x.

Kuźnar, A. (2007). International Trade in Services in Developing Countries Threats and Opportunities. Are Developing Counties Competitive? European Trade Study Group (ETSG), 2007 papers, Retrieved from http://www.etsg.org/ ETSG2007/papers/kuznar.pdf (30.05.2013).

Langhammer, R. J. (2004). Revealed Comparative Advantages in the Services Trade of the United States, the European Union and Japan: What Do They Tell us?. Journal of World Investment \& Trade, 5(6).

Laursen, K. (1998). Revealed Comparative Advantage and the Alternatives as Measure of International Specialization, Danish Research Unit for Industrial Dynamics, DRUID Working Paper, No. 98-30.

Lee, J. (2010). Export Specialization and Economic Growth Around the World. Economic Systems, 35(1). DOI: http://dx.doi.org/j.ecosys.2010.11.002.

Lennon, C. (2009). Trade in Services and Trade in Goods: Differences and Complementarities, WIIW Working Papers, no. 53, April 2009.

Liesner, H. H. (1958). The European Common Market and British Industry, Economic Journal, 68. DOI: http://dx.doi.org/10.2307/2227597. 
Markusen, J., Rutherford, T., \& Tarr, D. (2005). Trade and Direct Investment in Producer Services and the Domestic Market for Expertise. Canadian Journal of Economics, 38(3). DOI: http://dx.doi.org/10.1111/j.0008-4085.2005.00301.x.

Mongiało, D. (2007). Specjalizacja eksportowa krajów UE w międzynarodowym handlu usługami. Studia Europejskie, 3.

Prieto, F. (1989). Trade in Services: Some Comments on Comparative Advantage. Services Development: The Role of Foreign Direct Investment and Trade. United Nations.

Proudman, J., \& Redding, S. (2000). Evolving Patterns of International Trade. Review of International Economics, 8. DOI: http://dx.doi.org/10.1111/14679396.00229.

Snape, R. H. (1990). Principles in Trade in Services. In P. Messerlin \& K. P. Sauvant (Eds.). The Urugway Round. Services in the world economy. Washington, D.C: The World Bank, United Nations Centre on Transnational Corporation.

Stern, R. M., \& Hoekman, B. M. (1987). Issues and Data Needs for GATT Negotiations on Services. World Economy, 10(1).

Vollrath, T. L. (1991). A Theoretical Evaluation of Alternative Trade Intensity Measures of Revealed Comparative Advantage. Weltwirtschaftliches Archiv, 127(2).

Wróbel, A. (2009). Międzynarodowa wymiana ustug. Warszawa: Wydawnictwo Naukowe Scholar.

WTO (2013). WTO Statistical Data Sets - Metadata, Retrieved form http://stat.wto.org/StatisticalProgram/WSDBStatProgramTechNotes.aspx?Lang uage=E\#Def_Meth_Services.

Yeats, A. J. (1985). On the Appropriate Interpretation of Revealed Comparative Advantage Index: Implications of a Methodology Based on Industry Sector Analysis. Weltwirtschaftliches Archiv, 121. 